\title{
Effect of date palm (Phoenix dactylifera L.) leaves on productive performance of growing lambs
}

\author{
A. A. Mahrous ${ }^{1}$ - A. A. H. El-Tahan ${ }^{1}$ • Y. H. Hafez ${ }^{1}$ • M. A. El-Shora ${ }^{1}$ • O. A. Olafadehan ${ }^{2} \cdot$ H. Hamdon ${ }^{3}$
}

Received: 4 September 2020 / Accepted: 3 December 2020/Published online: 5 January 2021

(C) The Author(s) 2021

\begin{abstract}
Eighteen 4-month-old lambs, with a mean live weight (LW) of $19.47 \pm 0.20 \mathrm{~kg}$, were used to evaluate the nutritive value of date palm leaves (DPL) ensiled with different additives in a completely randomized design. Lambs were stratified into three groups of 6 lambs each and fed a control diet comprising 60\% concentrate feed mixture (CFM) and 40\% DPL silage (T1). In other treatments, the DPL silage (DPLS) of the control treatment was replaced with EM $_{1}$ additive-treated DPLS (T2) or El-Mofeed additive-treated DPLS (T3). Apparent digestibility, total digestible nutrient, digestible crude protein, dry matter intake, daily weight gain (DWG), price of DWG, daily profit, and economics of feed efficiency were higher $(P<0.05)$ for the additives-treated DPLS relative to the control, with T2 enhancing these parameters compared with T3. With exception of ruminal pH, which was reduced, concentrations of ruminal $\mathrm{NH}_{3}-\mathrm{N}$ and total volatile fatty acids (VFA) increased $4 \mathrm{~h}$ post feeding. However, ruminal $\mathrm{NH}_{3}-\mathrm{N}$ and total VFA were greater $(P<0.05)$ for the additives-treated DPLS, with $\mathrm{T} 2$ producing higher values than T3. Ruminal $\mathrm{pH}$ and feed cost $/ \mathrm{kg} \mathrm{LW}$ gain were lower for T2 relative to other treatments. Blood constituents were within the normal ranges for lambs, though slightly altered by treatments. Whereas serum total protein, albumin, and globulin were affected $(P<0.05)$ in this rank order, $\mathrm{T} 1<\mathrm{T} 3<\mathrm{T} 2$, other serum parameters were not affected. Relative feed cost and relative daily profit were lower and higher respectively for T2 than for T3. It is concluded that additives-treated DPLS is nutritionally superior to untreated DPLS as a roughage source in total mixed rations fed to growing lambs. However, for improved performance of the lambs and economic benefits, $\mathrm{EM}_{1}$-treated DPLS is recommended.
\end{abstract}

Keywords Additive $\cdot$ Date palm leaves $\cdot$ Silage $\cdot$ Digestibility $\cdot$ Weight gain

\section{Introduction}

Date fruit production yields several crop residues, including date palm fronds or leaves (DPL), petioles, racemes (without the dates), and pedicels. These by-products are usually used as feed for animals during winter, though they can be used year round (Genin et al. 2004). A date palm tree produces 13.5$20 \mathrm{~kg}$ DPL annually (Chehma and Longo 2001). FAO (2011) reported that 1.15 million ha of land were planted with palm

H. Hamdon

hamdon@nv.aun.edu.eg

1 Animal Production Research Institute, Agricultural Research Center, Dokki, Giza, Egypt

2 Department of Animal Science, University of Abuja, Abuja P.M.B. 117, Nigeria

3 Department of Animal Production, Faculty of Agriculture, New Valley University, New Valley, Egypt trees in Egypt. Base on average density of 100-125 date palm trees/ha, it was estimated that 1.9-2.4 million tons of dry leaves or fronds of date palm were available annually (Genin et al. 2004). Though DPL is available in large amounts, its utilization as animals feed is very limited due to the low nutritive value (Khalifa 2019). The composition of the leaves is $54.12 \%$ dry matter (DM), $89.86 \%$ organic matter (OM), $8.51 \%$ crude protein (CP), $28.48 \%$ crude fibre (CF), $59.11 \%$ neutral detergent fibre (NDF), $42.87 \%$ acid detergent fibre (ADF), 24.69\% hemicellulose, and $16.24 \%$ lignin (Olafadehan and Adebayo 2016). Due to anaerobic fermentation during silage preparation, silage has been used to improve the nutritive value of poor-quality roughages (Olafadehan and Adebayo 2016; Olafadehan and Okoye 2017). Date palm leaves have been reported to possess good silage quality when mixed with additives such as wheat bran and urea (Khorchani et al. 2004). Arbouche and Arbouche (2008) reported improved CP content and DM digestibility of DPL treated with ammonia. Although previous studies demonstrated the 
potentials of DPL in the diets of lactating cows (Bahman et al. 1997) and growing rabbits (El-Bordeny and Abdel-Azeem 2007), biological (use of desirable organisms for fermentation) and chemical (use of nutritive materials) treatment of DPL could further enhance its nutritive quality in livestock diet. It is expected that ensiling of crop residues with desirable organisms or nutritive additive would affect the silage quality differently due to different modes of action. However, information on nutritive value of additives-treated DPL silage (DPLS) in the diets of livestock is limited. It was hypothesized that feeding additive-treated DPLS as a source of roughage in the diets of growing lambs would improve feed intake, nutrient digestibility, ruminal fermentation, and growth performance, without compromising the blood metabolic profile. The aim of study was to evaluate the feed value of additivetreated DPL in the diets for growing lambs.

\section{Materials and methods}

\section{Additives for ensiling and silage preparation}

Two different additives were used for treating DPL before ensiling. The first additive, $\mathrm{EM}_{1}$, is a product of EMRO Organization in Japan (EM 1 Research Organization, Inc., Takamiyagi Bldg. 2F, 2-9-2 Gameko, Ginowan-shi Okinawa, Japan), containing a combination of 70 to 80 different types of beneficial microorganisms. The principal organisms are photosynthetic bacteria (phototrophic bacteria), lactic acid bacteria, yeasts, actinomycetes and fermenting fungi (Higa 1993). The second additive, El-Mofeed, is a nutritive product produced by El-Nobaria Station, Animal Production Research Institute, Agriculture Research Centre, Dokki, Giza, Egypt. It is made up of $91 \%$ molasses, $2.5 \%$ urea, and $6.5 \%$ solution containing a mixture of some mineral salts (calcium and manganese, magnesium, cobalt, copper, zinc, iodine, iron, potassium, and phosphorus) and vitamins A and D. Briefly, DPLS was produced by dissolving $5 \%$ each of the $\mathrm{EM}_{1}$ and El-Mofeed additives in $90 \mathrm{~L}$ of water. Each solution was mixed with $100 \mathrm{~kg}$ of DPL until the moisture content of the mixture was about $65-70 \%$. The treated DPL was packaged into polyethylene bags, put in air-tight containers, and left for 3 weeks after which the containers were opened and the silages air-dried before feeding.

\section{Lambs, diets, and management}

The study was carried out at Sakha Experimental Station, Animal Production Research Institute, Agriculture Research Centre, Egypt. Eighteen crossbred ram lambs ( $1 / 2$ Finnish Landrace $\times 1 / 2$ Rahmani) at 4 months of age $(19.47 \pm 0.20 \mathrm{~kg}$ LW) were used in a completely randomized design. They were weighed, divided into three homogenous groups (6 lambs/group), and housed individually in a 120-day feeding trial. Lambs were fed a control diet (T1) comprising 60\% DM concentrate feed mixture (CFM) and 40\% DM DPL to meet their nutrient requirements according to NRC (1985). In the other experimental diets, the $40 \%$ DPLS in the control diet was replaced with $40 \% \mathrm{EM}_{1}$ additive-treated DPLS (T2) or $40 \%$ El-Mofeed additive-treated DPLS (T3). Animals were randomly assigned to one of three experimental treatments and fed ad libitum, twice daily at 08:00 $\mathrm{h}$ and 15:00 h, to provide allowance for orts collection. The CFM and DPLS were sampled daily, composited weekly, oven dried at $60^{\circ} \mathrm{C}$ for $48 \mathrm{~h}$, and stored pending chemical analyses. The chemical composition of component of the diets is shown in Table 1 .

\section{Feed intake and apparent digestibility}

Feed intake was measured daily throughout the experimental period, while nutrient digestibility coefficients were determined using six animals for each ration at the end of the experimental period. Faeces were collected daily and oven dried at $60^{\circ} \mathrm{C}$ for $48 \mathrm{~h}$. The oven-dried daily faecal samples of each ram were bulked, thoroughly mixed, subsampled, and kept in a refrigerator for chemical analysis. Samples of feed, orts, and faeces were ground to pass a 1-mm screen using a Wiley mill (Arthur H. Thomas, Philadelphia, PA, USA) and analysed for dry matter (DM, method ID 934.01), ash (method ID 942.05), EE (method ID 956.02), and crude protein (CP, method ID 954.01) according to the methods of AOAC (2006). Fibre fractions, neutral detergent fibre (NDF), acid

Table 1 Chemical composition (\% DM unless otherwise stated) of untreated and treated date palm leaves silage and concentrate feed mixture (CFM)

\begin{tabular}{lrrrc}
\hline Item & \multicolumn{1}{c}{ T1 } & \multicolumn{1}{c}{ T2 } & \multicolumn{1}{c}{ T3 } & CFM* \\
\hline DM (\% fresh matter) & 94.44 & 90.50 & 89.30 & 88.7 \\
OM & 92.43 & 87.38 & 85.55 & 92.82 \\
CP & 4.20 & 7.50 & 5.60 & 14.16 \\
CF & 43.01 & 39.32 & 41.87 & 11.05 \\
EE & 2.31 & 1.15 & 1.16 & 2.3 \\
NFC & 42.91 & 39.41 & 36.92 & 65.31 \\
NDF & 81.65 & 74.20 & 77.32 & 27.79 \\
ADF & 67.72 & 59.31 & 61.22 & 8.86 \\
ADL & 37.84 & 26.05 & 28.30 & 2.89 \\
Cellulose & 29.88 & 33.26 & 32.92 & 5.88 \\
Hemicellulose & 13.93 & 14.89 & 16.10 & 18.89 \\
\hline
\end{tabular}

* Concentrate feed mixture (CFM) consisted of $38 \%$ ground yellow corn, $22 \%$ undecorticated cotton seed meal, $7 \%$ soybean meal, $12 \%$ wheat bran, $13 \%$ rice bran, $5 \%$ cane molasses, $2 \%$ lime stone, and $1 \%$ common salt

$T 1$ untreated DPLS, T2 DPLS treated with $\mathrm{EM}_{1}, T 3$ DPLS treated with El-Mofeed 
detergent fibre (ADF), and acid detergent lignin (ADL) were determined according to Van Soest et al. (1991). Hemicellulose and cellulose were calculated as the differences between NDF and ADF and ADF and ADL, respectively. Non-fibre carbohydrate NFC was estimated as $\mathrm{NFC}=100-$ $(\mathrm{NDF}+\mathrm{CP}+\mathrm{EE}+\mathrm{ash}) \%$.

\section{Ruminal fluid collection and analysis}

At the end of the experiment trials, rumen fluid samples were taken from six animals of each group using stomach tube before feeding and $4 \mathrm{~h}$ post feeding. The samples were filtered through 3 layers of gauze. Ruminal $\mathrm{pH}$ was measured immediately using $\mathrm{pH}$ metre (Orion Research, model 201/digital pH metre). Ammonia nitrogen $\left(\mathrm{NH}_{3}-\mathrm{N}\right)$ concentration was measured according to Conway and O'Mally (1957). Total volatile fatty acids (VFA) concentration was determined by the steam distillation method according to Abou-Akkada and Osman (1967).

\section{Blood collection and analysis}

Blood samples were drawn from the jugular veins of six animals of each group at $4 \mathrm{~h}$ after morning feeding and centrifuged for $20 \mathrm{~min}$ at $3000 \mathrm{rpm}$. The supernatant was collected, frozen, and stored at $-20{ }^{\circ} \mathrm{C}$ for subsequent analysis. Blood serum was analysed for total protein (Armstrong and Carr 1964), albumin (Doumas et al. 1971), creatinine (Folin 1994), urea (Siest et al. 1981), and cholesterol (Fassati and Prenciple 1982). Amino aspartate transaminase (AST) and alanine transaminase (ALT) were determined calorimetrically by the methods of Reitman and Frankel (1957), using commercial kits (Biodiagnostic, Dokki, Giza, Egypt). Globulin concentration was calculated by subtracting albumin concentration from the corresponding total protein concentration.

\section{Statistical analysis}

Data were analysed as a completely randomized design using the general linear model of SAS 9.1.3 (SAS Institute Inc., Cary, North Carolina, USA). The following mathematical model was used:

$\mathrm{Y}_{\mathrm{ij}}=\mu+\mathrm{T}_{\mathrm{i}}+\mathrm{e}_{\mathrm{ij}}$

where $Y_{i j}$ is the observation on the experimental unit, $\mu$ is the overall mean, $T_{i}$ is the effect due to treatment, and $e_{i j}$ is the experimental error.

Duncan's multiple range test was used to separate significant treatment means, and significance was declared if $P<0.05$.

\section{Results and discussion}

\section{Chemical composition}

Additive treatments of DPL decreased the DM, OM, fibre fractions, and NFC but increased CP (Table 1). $\mathrm{EM}_{1}$ and ElMofeed increased DPLS CP by 74.3 and $33.3 \%$ but decreased NDF, ADF, and ADL by 9.0 and $5.3 \%, 12.4$ and $9.6 \%$, and 31.2 and $23.2 \%$, respectively. The chemical composition of the untreated DPLS is consistent with the earlier reports (Pascual et al. 2000; Kafilzadeh et al. 2009; El-Waziry et al. 2013). The increased CP and decreased fibre fractions indicate that additive treatments improved the nutritive value of DPLS. The results agree with those of Villas-Boas et al. (2002) who observed that biological treatment of poorquality by-products increased their nutritional value because of significant increase in the concentrations of $\mathrm{CP}$ and NFC (soluble carbohydrates) and reduction in fibre fractions. The reduced fibre fractions of the additivestreated DPLS may be due to the catabolic action of certain fermentative microorganisms which utilize carbohydrate as a carbon source for growth and formation of microbial protein (Olafadehan et al. 2012; Olafadehan and Adebayo 2016). The relatively higher $\mathrm{CP}$ and lower fibre fractions of the T2 compared to T3 show that DPLS treated with EM 1 (fermentative organisms containing additive) improved anaerobic fermentation efficiency and thus nutritive value of DPLS compared to DPLS treated with El-Mofeed (nutritive additive containing molasses, urea, some minerals, and vitamins $\mathrm{A}$ and D).

\section{Apparent digestibility and nutritive value}

Additive treatments (T2 and T3) increased $(P<0.05)$ the nutrient digestibility, digestible crude protein (DCP), and total digestible nutrient $(\mathrm{TDN})$, with $\mathrm{T} 2\left(\mathrm{EM}_{1}\right.$-treated DPLS) producing better $(P<0.05)$ results compared with El-Mofeed-treated DPLS (T3) (Table 2). The improved nutrient digestibility with additives-treated DPLS may be due to reduced fibre fraction, particularly ADL, of the diets. Lignin is a recalcitrant fibre that resists both microbial and enzymatic digestion and consequently lowers nutrient digestibility (Olafadehan and Adebayo 2016). Moreover, the additive treatments must have promoted faster degradation and clearance from the gastrointestinal tract, in tandem with the previous submissions of Olafadehan (2013). The improved fibre digestibility of the additive treatments suggests improved ruminal fermentation efficiency and microbial biomass production, increased number and/or activity of ruminal microbiota, and enhanced colonization and attachment of the ruminal microbes to the digesta (Nsereko et al. 2000; Wang et al. 2001; Olafadehan 2013). The chemical composition, TDN, and DCP of a diet have been used 
Table 2 Apparent digestibility and nutritive value of additives-treated date palm leaves silage fed to lambs

\begin{tabular}{lcccc}
\hline Item (\%) & \multicolumn{2}{l}{ Experimental treatments } & \multirow{2}{*}{ \pm SEM } \\
\cline { 2 - 4 } & $\mathrm{T} 1$ & $\mathrm{~T} 2$ & $\mathrm{~T} 3$ & \\
\hline Dry matter & $54.12^{\mathrm{c}}$ & $64.77^{\mathrm{a}}$ & $60.18^{\mathrm{b}}$ & 0.18 \\
Organic matter & $54.53^{\mathrm{c}}$ & $63.23^{\mathrm{a}}$ & $60.47^{\mathrm{b}}$ & 0.22 \\
Crude protein & $55.34^{\mathrm{c}}$ & $63.3^{\mathrm{a}}$ & $60.94^{\mathrm{b}}$ & 0.50 \\
Ether extract & $68.2^{\mathrm{c}}$ & $75.74^{\mathrm{a}}$ & $74.2^{\mathrm{b}}$ & 0.34 \\
Non-fibre carbohydrate & $58.68^{\mathrm{c}}$ & $65.1^{\mathrm{a}}$ & $62.4^{\mathrm{b}}$ & 0.05 \\
Neutral detergent fibre & $58.88^{\mathrm{c}}$ & $64.40^{\mathrm{a}}$ & $62.60^{\mathrm{b}}$ & 0.32 \\
Acid detergent fibre & $41.33^{\mathrm{c}}$ & $55.43^{\mathrm{a}}$ & $54.50^{\mathrm{b}}$ & 0.45 \\
Acid detergent lignin & $32.62^{\mathrm{c}}$ & $38.82^{\mathrm{a}}$ & $39.85^{\mathrm{b}}$ & 0.65 \\
Cellulose & $14.48^{\mathrm{c}}$ & $19.95^{\mathrm{a}}$ & $16.92^{\mathrm{b}}$ & 0.22 \\
Hemicellulose & $47.83^{\mathrm{c}}$ & $58.89^{\mathrm{a}}$ & $54.32^{\mathrm{b}}$ & 0.34 \\
Nutritive value & & & & \\
Total digestible nutrient & $52.04^{\mathrm{c}}$ & $60.59^{\mathrm{a}}$ & $54.42^{\mathrm{b}}$ & 0.55 \\
Digestible crude protein & $5.63^{\mathrm{c}}$ & $7.32^{\mathrm{a}}$ & $6.35^{\mathrm{b}}$ & 0.05 \\
\hline a, b, c Means in the same row with different superscript are significantly \\
$(P<0.05)$
\end{tabular}

as indices of the nutritive value (Olafadehan 2013). Both TDN and DCP are products of apparent digestibility and dietary nutrient profile. Therefore, the enhanced chemical composition and nutrient digestibility of the additive treatments are responsible for the improved TDN and DCP. Based on the chemical composition (higher CP and lower fibre fraction), $\mathrm{EM}_{1}$ produced silage of superior quality relative to El-Mofeed produced silage. This is reflected in the greater nutrient digestibility, DCP, and TDN of the $\mathrm{EM}_{1}$ treatment relative to El-Mofeed treatment. These results suggest $\mathrm{EM}_{1}$ as a better additive for ensiling of crop residues than El-Mofeed. $\mathrm{EM}_{1}$ additive is a combination of desirable fermentative organisms or inoculants such as lactic acid bacteria, yeasts, and fermenting fungi, while ElMofeed is a kind of additive containing fermentation/ ensiling aiding nutrients such as molasses and urea. AbdEl-Ghany et al. (2016) earlier showed EM $_{1}$-treated berseem hay improved nutrient digestion and nutritive value of the hay in rabbit diet. Kholif et al. (2005) and Mahrous et al. (2005) found that fungal treated roughages increased $(P<0.05)$ nutrient digestibility and nutritive value (TDN and DCP).

\section{Rumen parameters}

Ruminal $\mathrm{pH}$ followed this rank order: $\mathrm{T} 1<\mathrm{T} 3<\mathrm{T} 2(P<0.05)$ (Table 3). Greater ruminal $\mathrm{pH}$ of the treatments may be due to the lower fibre fractions of the diets. Low fibre diets reduced rates of chewing and saliva secretion and flow into the rumen to buffer the ruminal pH (Olafadehan and Adebayo 2016;
Table 3 Rumen fermentation parameters of lambs fed additives-treated date palm leaves silage

\begin{tabular}{|c|c|c|c|c|c|}
\hline \multirow[t]{2}{*}{ Item } & \multicolumn{4}{|c|}{ Experimental treatments } & \multirow[t]{2}{*}{$\pm \mathrm{SEM}$} \\
\hline & Time $(\mathrm{h})$ & $\mathrm{T} 1$ & $\mathrm{~T} 2$ & $\mathrm{~T} 3$ & \\
\hline \multirow[t]{2}{*}{$\mathrm{pH}$} & 0 & $6.44^{\mathrm{c}}$ & $6.67^{\mathrm{a}}$ & $6.52^{\mathrm{b}}$ & 0.06 \\
\hline & 4 & $6.40^{\mathrm{a}}$ & $6.19^{\mathrm{c}}$ & $6.20^{\mathrm{b}}$ & 0.04 \\
\hline \multirow[t]{2}{*}{$\mathrm{NH}_{3}-\mathrm{N}(\mathrm{mg} / 100 \mathrm{ml})$} & 0 & $14.05^{\mathrm{a}}$ & $19.28^{\mathrm{c}}$ & $16.51^{\mathrm{b}}$ & 0.08 \\
\hline & 4 & $20.95^{\mathrm{c}}$ & $28.01^{\mathrm{a}}$ & $24.39^{\mathrm{b}}$ & 0.45 \\
\hline \multirow[t]{2}{*}{ TVFA (meq/100 ml)* } & 0 & $9.54^{\mathrm{c}}$ & $13.44^{\mathrm{a}}$ & $12.50^{\mathrm{b}}$ & 0.55 \\
\hline & 4 & $12.62^{\mathrm{c}}$ & $17.70^{\mathrm{a}}$ & $14.68^{\mathrm{b}}$ & 0.54 \\
\hline
\end{tabular}

Olafadehan et al. 2016; Okunade and Olafadehan 2019). Sheep fed untreated DPLS (control) had highest $(P<0.05)$ ruminal $\mathrm{NH}_{3}-\mathrm{N}$ values at 0 and $4 \mathrm{~h}$ post feeding followed by $\mathrm{T} 2$ and $\mathrm{T} 3$. The ruminal $\mathrm{NH}_{3}-\mathrm{N}$ concentrations for all treatments at 0 and $4 \mathrm{~h}$ post feeding were greater than the minimal level of $5 \mathrm{~g} \mathrm{NH}_{3}-\mathrm{N} / \mathrm{L}$ required for optimum rumen microbes growth and activity (Satter and Slyter 1974). This may be related to improved utilization of the dietary energy and enhanced fermentation in the rumen. Molina-Alcaide and Nefzaoui (1996) indicated that feeding date palm cake to sheep resulted in favourable $\mathrm{pH}$ (6.2 to 7.2) for fibrolytic activity. Higher ruminal $\mathrm{NH}_{3}-\mathrm{N}$ of $\mathrm{T} 1$ indicates rapid proteolysis of the dietary protein, in consonance with earlier reports (Olafadehan and Adebayo 2016; Olafadehan et al. 2020). Excess dietary $\mathrm{N}$ loss via urine due to rapid proteolysis contributes to environmental degradation and inefficiencies in ruminant production (Olafadehan et al. 2020). Lower ruminal $\mathrm{NH}_{3}-\mathrm{N}$ of the treatments, particularly $\mathrm{T} 3$, is beneficial as it indicates reduced dietary $\mathrm{CP}$ deamination and loss. Hassan et al. (2005) reported increased ruminal $\mathrm{NH}_{3}-\mathrm{N}$ for rams fed untreated banana wastes compared to biologically treated groups. Treatments T2 and T3 significantly $(P<0.05)$ increased the concentration of VFA. Increased VFA for the treatments may be due to improved nutrient digestibility and ruminal fermentation (Kholif et al. 2018a, b). The results are in agreement with those obtained by Mahrous et al. (2011) and Bassuny et al. (2003) who reported that rumen VFA concentrations were significantly increased with biological and chemical treatments of roughages. The decreased ruminal $\mathrm{NH}_{3}-\mathrm{N}$ and enhanced total VFA concentrations of treatments relative to the control are nutritionally desirable for improved performance of ruminants because VFA is used as an energy source and as substrates for the synthesis of other compounds (Kholif et al. 2018a). Though both T2 and T3 enhanced ruminal fermentation efficiency relative to $\mathrm{T} 1, \mathrm{~T} 2$ provided better results than $\mathrm{T} 3$. 


\section{Blood serum parameters}

In the present study, all the serum metabolites were within the normal physiological ranges (Merck 1991). Total serum protein, albumin, and globulin followed the rank order: T2 > T3 $>\mathrm{T} 1(P<0.05)$ (Table 4). Increased serum total protein, albumin, and globulin with additives-treated DPLS diets may be attributed to improved metabolic process as a response to increased nutrient intake and digestibility, especially $\mathrm{CP}$ and $\mathrm{OM}$ as well as increased flow of microbial protein from the rumen (Yang et al. 1999). Moreover, Kumar et al. (1980) and Ayling (2014) reported that blood total proteins concentrations reflect the nutritional status of an animal and are positively correlated with dietary protein level. These results agree with those reported by Abd ElRazik et al. (2012) who found that lambs fed diets containing biologically treated rice straw had higher values of blood total protein, albumin, and albumin:globulin ratio. Blood serum creatinine, urea, AST, ALT, cholesterol, and glucose were not affected by treatments. Normal values and lack of treatment effect on serum creatinine, urea, AST, and ALT suggest normal liver activity and function (Olafadehan 2011a).

\section{Growth performance and economic efficiency}

Total body gain, daily gain, and feed intake were higher $(P<0.05)$ for lambs fed additives-treated DPLS diets compared with control, but $\mathrm{T} 2$ improved these parameters relative to T3. Feed conversion was lowest for T2 followed by T3 and T1 (Table 5). Higher feed intake of additives treatments is due to improved palatability, reduced fibre, and greater $\mathrm{CP}$ and digestibility of the diets, in concurrence with previous reports (Olafadehan et al. 2014) who attributed improved intake in

Table 4 Blood metabolites of lambs fed additives-treated date palm leaves silage

\begin{tabular}{lllll}
\hline \multirow{2}{*}{ Item } & \multicolumn{2}{l}{ Experimental treatments } & \multirow{2}{*}{ \pm SEM } \\
\cline { 2 - 4 } & $\mathrm{T} 1$ & $\mathrm{~T} 2$ & $\mathrm{~T} 3$ & \\
\hline Total protein $(\mathrm{g} / \mathrm{dl})$ & $6.21^{\mathrm{c}}$ & $6.98^{\mathrm{a}}$ & $6.50^{\mathrm{b}}$ & 0.35 \\
Albumin $(\mathrm{g} / \mathrm{dl})$ & $3.49^{\mathrm{c}}$ & $3.79^{\mathrm{a}}$ & $3.64^{\mathrm{b}}$ & 0.19 \\
Globulin $(\mathrm{g} / \mathrm{dl})$ & $2.72^{\mathrm{c}}$ & $3.19^{\mathrm{a}}$ & $2.86^{\mathrm{b}}$ & 0.26 \\
Creatinine $(\mathrm{mg} / \mathrm{dl})$ & 1.30 & 1.28 & 1.28 & 0.11 \\
Urea nitrogen $(\mathrm{mg} / \mathrm{dl})$ & 42.22 & 41.05 & 40.21 & 3.48 \\
Alanine transaminase $(\mathrm{U} / \mathrm{ml})$ & 19.50 & 20.44 & 19.49 & 2.61 \\
Aspartate transaminase $(\mathrm{U} / \mathrm{ml})$ & 39 & 41 & 40 & 3.67 \\
Cholesterol $(\mathrm{mg} / \mathrm{dl})$ & 150.2 & 152.1 & 149.9 & 4.40 \\
\hline
\end{tabular}

$\mathrm{a}, \mathrm{b},{ }^{\mathrm{c}}$ Means within the same row with different superscripts differ $(P<0.05)$ goats fed bovine rumen content to increased palatability, acceptance and consumption, rumen fermentation and digestibility, and shortened transit time of the digesta passage through the gastrointestinal tract. The greater intake of T2 than T3 further illustrates the superior nutritive value of $\mathrm{EM}_{1}$-treated DPLS relative to the El-Mofeed-treated DPLS. Body weight gain in animals is largely a function of feed intake, ruminal fermentation efficiency, and digestibility. Therefore, the reduced weight gain of the control goats is obviously the fallout of the decreased intake, ruminal fermentation, and digestibility, while the increased weight gain of the treatments is the result of enhanced feed utilization. Using enzyme additive, Beauchemin et al. (1995) attributed improvement in live weight with enzyme additive to increased digestibility, which yields more energy and/or nutrient to rumen microbes. Treatments $\mathrm{T} 2$ and $\mathrm{T} 3$ increased daily gain by 32.1 and $24.3 \%$, respectively, relative to the control, while daily gain was $6.3 \%$ greater in $\mathrm{T} 2$ compared to $\mathrm{T} 3$. Improved feed utilization of $\mathrm{T} 2$ and $\mathrm{T} 3$ resulted in reduced feed conversion relative to T1. Similar trend was obtained by El-Marakby (2003) and Mahrous et al. (2005) who reported that groups fed ration containing biologically treated wheat straw or cotton stalks had improved feed conversion relative to the group fed the untreated roughages. Also, El-Marakby (2003) indicated that groups fed biologically treated roughages (cotton stalks or wheat straw) had better efficient feed conversion. Though total daily feed cost was lower $(P<0.05)$ in $\mathrm{T} 1$, price of daily gain, daily profit, and economics of feed efficiency increased in T2 and T3 compared to T1, with T2 having greater values than T3 (Table 5). Feed cost $/ \mathrm{kg} \mathrm{LW}$ gain was reduced $(P<0.05)$ in $\mathrm{T} 2$ and $\mathrm{T} 3$, indicating that it was significantly cheaper and more economical to produce $1 \mathrm{~kg}$ of LW with additives-treated DPLS than for the control untreated DPLS. This is in agreement with the previous studies where processed cassava peels reduced feed cost $/ \mathrm{kg}$ LW gain relative to the unprocessed peels in rabbit diets (Olafadehan 2011b). There were 18.6 and $16.1 \%$ reductions in feed cost $/ \mathrm{kg} \mathrm{LW}$ gain in T2 and T3, respectively, relative to the T1. Daily profit and economics of feed efficiency were 65.5 and $44.8 \%$ and 52.6 and $38.1 \%$ greater for $\mathrm{T} 2$ and T3, respectively, relative to T1. El-Tahan et al. (2013) observed improved net revenue and economic efficiency in sheep fed fungi-treated palm fronds. Abd-ElGhany et al. (2016) reported increased economic efficiency in rabbits fed diets containing $\mathrm{EM}_{1}$-treated conocarpus at 15 or $30 \%$ compared to those fed the control diet. Relative daily profit was $14.2 \%$ higher in T2 than in T3, indicating superior nutritive and economic benefit of $\mathrm{EM}_{1}$-treated DPLS relative to El-Mofeed-treated DPLS in the lambs' diets. Olafadehan et al. (2018) attributed greater economic benefits in goats fed Piliostigma thonningii foliage in partial replacement of concentrate to superior quality of the foliage relative to the locally produced concentrate. 
Table 5 Intake, growth, and economics of production of lambs fed additives-treated palm date leaves silage

\begin{tabular}{|c|c|c|c|c|}
\hline \multirow[t]{2}{*}{ Item } & \multicolumn{3}{|c|}{ Experimental treatments } & \multirow[t]{2}{*}{$\pm \mathrm{SEM}$} \\
\hline & $\mathrm{T} 1$ & $\mathrm{~T} 2$ & $\mathrm{~T} 3$ & \\
\hline Initial live body weight, $\mathrm{Kg}$ & 19.60 & 19.40 & 19.40 & 0.02 \\
\hline Final live body weight, $\mathrm{Kg}$ & $36.50^{\mathrm{c}}$ & $41.80^{\mathrm{a}}$ & $40.40^{\mathrm{b}}$ & 1.21 \\
\hline Total body gain, $\mathrm{Kg}$ & $16.90^{\mathrm{c}}$ & $22.40^{\mathrm{a}}$ & $21.00^{\mathrm{b}}$ & 1.23 \\
\hline Daily gain, $\mathrm{g}$ & $140.80^{\mathrm{c}}$ & $186.60^{\mathrm{a}}$ & $175.00^{\mathrm{b}}$ & 1.69 \\
\hline \multicolumn{5}{|l|}{ Feed intake/day (DMI) (g) } \\
\hline CFM & $650^{\mathrm{c}}$ & $700^{\mathrm{a}}$ & $680^{\mathrm{b}}$ & 0.93 \\
\hline DPLS & $200^{\mathrm{c}}$ & $260^{\mathrm{a}}$ & $240^{\mathrm{b}}$ & 2.45 \\
\hline Total DM, g & $850^{\mathrm{c}}$ & $960^{\mathrm{a}}$ & $920^{\mathrm{b}}$ & 2.11 \\
\hline Feed conversion (DMI $\mathrm{Kg} / \mathrm{Kg}$ gain) & $6.03^{\mathrm{a}}$ & $4.62^{\mathrm{c}}$ & $5.25^{\mathrm{b}}$ & 1.32 \\
\hline \multicolumn{5}{|l|}{ Economic efficiency } \\
\hline Price of daily gain, LE & $8.40^{\mathrm{c}}$ & $11.19^{\mathrm{a}}$ & $10.50^{\mathrm{b}}$ & 1.02 \\
\hline \multicolumn{5}{|l|}{ Daily feed cost (LE) } \\
\hline Cost of CFM consumed & $2.93^{\mathrm{c}}$ & $3.15^{\mathrm{a}}$ & $3.06^{\mathrm{b}}$ & 0.45 \\
\hline Cost of DPLS consumed & $0.14^{\mathrm{c}}$ & $0.18^{\mathrm{a}}$ & $0.16^{\mathrm{b}}$ & 0.03 \\
\hline Total daily feed cost, LE & $3.07^{\mathrm{c}}$ & $3.33^{\mathrm{a}}$ & $3.22^{\mathrm{b}}$ & 0.34 \\
\hline Feed cost $/ \mathrm{kg}$ gain, $\mathrm{LE}$ & $36.54^{\mathrm{a}}$ & $29.75^{\mathrm{c}}$ & $30.66^{\mathrm{b}}$ & 0.43 \\
\hline Daily profit, LE & $4.26^{\mathrm{c}}$ & $7.05^{\mathrm{a}}$ & $6.17^{\mathrm{b}}$ & 1.66 \\
\hline Economics of feed efficiency, $\% *$ & $138.76^{\mathrm{c}}$ & $211.71^{\mathrm{a}}$ & $191.61^{\mathrm{b}}$ & 0.02 \\
\hline Relative feed cost, $\% * *$ & - & $81.41^{\mathrm{b}}$ & $83.90^{\mathrm{a}}$ & 0.23 \\
\hline Relative daily profit, $\% * * *$ & - & $165.40^{\mathrm{a}}$ & $144.83^{\mathrm{b}}$ & 1.02 \\
\hline
\end{tabular}

$1 \mathrm{t}$ of CFM $=4500$ LE. $1 \mathrm{t}$ of untreated DPL $=600$ LE. $1 \mathrm{t}$ of EM1-treated DPLS $=700$ LE. $1 \mathrm{t}$ of El-Mofeedtreated DPLS $=700$. Market price of $1 \mathrm{~kg}$ live body weight $=60 \mathrm{LE}$

$*$ Economic feed efficiency, $\%=$ daily profit/daily feed cost $\times 100$

**Relative feed cost, $\%=$ feed cost, LE/kg gain (T2 and T3)/T1

$* * *$ Relative daily profit, $\%=$ Daily profit LE $(\mathrm{T} 2$ and $\mathrm{T} 3) / \mathrm{T} 1$

a, b, c Means within the same row with different superscripts differ $(P<0.05)$

\section{Conclusion}

It can be concluded that incorporation of $\mathrm{EM}_{1}$ - and ElMofeed-treated DPLS in lambs' total mixed rations improves voluntary intake, ruminal fermentation, nutrient digestibility, nutritive value, economic benefit, and growth performance. However, $\mathrm{EM}_{1}$ additive improved the quality of DPLS and performance of lambs compared with ElMofeed additive.

Acknowledgments The authors are grateful to the staff of Sakha Experimental Station, Animal Production Research Institute, Agriculture Research Centre for helping in carrying out the experiment.

\section{Compliance with ethical standards}

Competing interest The authors declare that they have no competing interest.

Ethical approval All applicable international, national, and/or institutional guidelines for the care and use of animals were followed.
Open Access This article is licensed under a Creative Commons Attribution 4.0 International License, which permits use, sharing, adaptation, distribution and reproduction in any medium or format, as long as you give appropriate credit to the original author(s) and the source, provide a link to the Creative Commons licence, and indicate if changes were made. The images or other third party material in this article are included in the article's Creative Commons licence, unless indicated otherwise in a credit line to the material. If material is not included in the article's Creative Commons licence and your intended use is not permitted by statutory regulation or exceeds the permitted use, you will need to obtain permission directly from the copyright holder. To view a copy of this licence, visit http://creativecommons.org/licenses/by/4.0/.

\section{References}

Abd El-Razik, M. I.; Abd-Elrahman G. A,and Ayyat M. S. 2012. Effect of biological and chemical treatments of rice straw on lamb performance. Zagazig J. Agric. Res., 39 (4): 655-664

Abd-El-Ghany, F.T.F., Ali W.A.H., Mahmoud M.A., and Abdel-Mawla L.F.2016. Effect of partial replacement of berseem hay by biologically treated conocarpus on productive performance and physiological response of growing rabbits. The 9th International Poultry 
Conference of the Egyptian Poultry Science Association, 7 - 10 November, Hurgada- Egypt.

Abou-Akkada, A. R., and Osman H. E. 1967. Studies on the utilization of non-protein nitrogen in Egypt. J. Agric. Sci., 169: 25-33.

AOAC. 2006. Association of Official Analytical Chemists International. Official Methods of Analysis, 18th ed. Current through Revision 1. AOAC, Gaithersburg, MD.

Arbouche, F. \& Arbouche, H. S. (2008). Date by-products from southeast Algeria: effects of treatment with urea and the mode of storage on their chemical composition and digestibility. Livest. Res. Rural Dev., 20 (6): 97

Armstrong, W.D, and Carr C. W. 1964. Physiological. Chemistry, 3rd ed. pp., 75 Burges Publishing CO.Minneapolis, Minnesota, USA.

Ayling, R.M. 2014. Clinical bioche AS, In Marshall, W; Lapsley, M; Day, A.P. and Ayling, R.M. (Eds) Clinical biochemistry, metabolic and clinical aspects. Third Ed. Elsevier Limited. pp. 180-199.

Bahman, A. M.; Topps, J. H., and Rooke, J. A. 1997. Use of date palm leaves in high concentrate diets for lactating Friesian and Holstein cows. J. Arid Environ., 35: 141-146

Bassuny, S.M.; Abdel-Aziz A.A.; El-Sayis M. F., and Aabdulla M.A. 2003. Fibrous crop by-products as feed. 2. Effect of chemical and biochemical treatments on feed intake, nutritive values and some ruminal and blood constituents. Egyptian J. Nutrition and feeds. (6) Special Issue: 901-912.

Beauchemin, K. A.; Rode L. M. V. and Sewalt J. H. 1995. Fibrolytic enzymes increase fiber digestibility and growth rate of steers fed dry forages. Can. J. Anim. Sci. (75): 641-644.

Chehma, A. and Longo H. F. 2001. Bilan azote et gain de poids, chez le dromadaire et le mouton, alimentes a base de sous-produits du palmier dattier, de la paille d'orge et du drinn Aristida pungens. Cahiers Agricultures. 13(2): 221-226.

Conway, E.F., and O'Mally E. 1957. Micro diffusion methods. Ammonia and urea using buffered absorbents. Biochem. J., 36: 655-668.

Doumas, B. T.; Wastson W. A., and Bhmiggs H. G. 1971. Albumin standards and the measurement of serum albumin with bromocresol green. Clin. Chem. Acta., 31:87-90.

El-Bordeny, N.E, and Abdel-Azeem F. 2007. Utilization of palm tree leaves in feeding growing rabbits. Egyptian, J. Nutrition and feeds, $10(2): 275-288$

El-Marakby, K. M. A. 2003 Biological treatments of poor quality roughage and its effect on productive performance of ruminants. MSc Thesis, Animal Production Department, Faculty of Agriculture, Zagazig University, Egypt.

EL-Tahan, A. A. H.; Mohammadi T. F.; Bakr A. A.; EL-Bltagy E. and Abo-El-Ella A. 2013. Upgrading palm fronds through different treatments to use as animal feed: 1- Using of biologically tree palm fronds grinded ted in sheep ration. Egyptian J. Nutrition and Feeds. 16(2) 235- 242

El-Waziry, A. M.; Alkoaik F.; Khalil A. I.; Metwally H.; and AlMahasneh M. A. 2013. Estimation of degradability kinetics, energy and organic matter digestibility of date Palm (Phoenix dactylifera L.) leaves silage by in vitro gas production technique. Asian J. Anim. Vet. Adv. (8): 814-820.

FAO. FAOSTAT. 2011. Food and Agriculture Organization of the United Nations.

Fassati P, and Prenciple L. 1982. Colorimetric of determination of cholesterol. Clin. Chem. 28.2077.

Folin, O.Z. 1994. Colorimetric of determination of plasma creatinine. Phys. Chem., 268: 228.

Genin, D.; Kadri, A.; Khorchani, T.; Sakkal, K.; Belgacem, F. and Hamadi, M. 2004 Valorisation of date-palm by-products (DPBP) for livestock feeding in southern Tunisia. 1- Potentialities and traditional utilisation. In: Ben Salem, H., Nefzaoui A., Morand-Fehr, P. (eds). Nutrition and feeding strategies of sheep and goats under harsh climates (Stratégies de nutrition et d'alimentation des ovins et caprins en climatsrigoureux), Zaragoza: CIHEAM-IAMZ, 227232

Hassan, A. A.; Yacout H. M.; Mohsen M. K. K.; Bassiouni M. I., and Abd-Ell M. 2005. Banana Wastes (Musa acuminate L) silage treated biologically or with urea for dairy cows feeding. Egyptian J. Nutr. and Feeds, 8: 49-64.

Higa T 1993: Revolution for helping world. Bangkok, Sukjai Publishing, pp. 199.

Kafilzadeh, F.; Hozhabri F.; and Kabirifarad A. 2009. Effect of Pleurotus florida on in vitro gas production of wheat stubble and date palm leaf. Res. J. Biol. Sci. 4(1): 37-41.

Khalifa A. M. A. 2019. Productive performance of lambs fed on rations containing date palm leaves. MSc Thesis, Faculty of Agriculture, Assuit University, Assuit, Egypt.

Kholif, A. M.; El-Ashry M. A.; El-Alamy H. A.; El-Sayed H. M.; M. Fadel and S. M. Kholif. 2005. Biological treatments banana wastes for feeding lactating goats. Egyptian Journal of Nutrition and Feeds, 8 (2): 149-162.

Kholif, A.E., Gouda, G.A., Olafadehan, O.A. and, Abdo, M.M. $2018 \mathrm{a}$. Effects of replacement of Moringa oleifera for berseem clover in the diets of Nubian goats on feed utilisation, and milk yield, composition and fatty acid profile. Animal, 12: 964-972.

Kholif, A.E., Kassab, A.Y., Azzaz, H.H., Matloup O.H., Hamdon, H.A., O.A. Olafadehan and Morsy, T.A. 2018b. Essential oils blend with a newly developed enzyme cocktail works synergistically to enhance feed utilization and milk production of Farafra ewes in the subtropics. Small Ruminant Research 161: 43-50.

Khorchani, T.; Hammadi, M.; El-Jani, H.; Genin, D.; Sakkal, K., and Abdouli, H.V. 2004 Valorization of date-palm by-products (DPBP) for livestock feeding in Southern Tunisia. IICharacteristics and digestibility of DPBP-based silages. In: Ben Salem, H., Nefzaoui A., Morand-Fehr, P. (eds). Nutrition and Feeding Stratégies of Sheep and Goats under Harsh Climates. Zaragoza: CIHEAM-IAMZ, 227-232.

Kumar, N. U.; Singh B., and Berma D. N. 1980. Effect of different levels of dietary protein and energy on growth of male buffalo calves. Ind. J. Anim. Sci., 15: 513 - 517.

Mahrous, A. A., El-Shafie M. H., and Abdel-Khalek T. M. 2005. Effect of biological, chemical and chemic-biological treatments on the nutritive value of corn cobs. Proc. 2 Res. Inst. Sakha, ,27-29 Sept., 269.

Mahrous A. A.; El-Shafie E. H.and Abdel- Khalek T. M. M. 2011. Performance of Growing lambs fed fungus treated sugarcane bagasse. Egyptian J. of Sheep and Goat Sci., 6(1): 27-35.

Merck. 1991. The Merck Veterinary Manual., Seven Edition.

Molina-Alcaide E., and Nefzaoui A. 1996. Recycling of olive oil byproducts: possibilities of utilization in animal nutrition. Int Biodeterior Biodegrad. 38:227-235.

National Research Council. 1985. Nutrient requirements of sheep. 6th ed. Washington DC, USA: National Academy Press;

Nsereko, V. L.; Morgavi D. P.; Rode L. M.; Beauchemin K. A, and McAllister T. A. 2000, Effects of fungal enzyme preparations on hydrolysis and subsequent degradation of alfalfa hay fiber by mixed rumen microorganisms in vitro. Anim. Feed Sci. Technol. (88): $153-170$.

Okunade, S.A. and Olafadehan, O.A. 2019. Rolfe (Daniellia oliveri) seed meal as a protein source in locally produced concentrates for lambs fed low quality basal diet. J. Saudi Soc. Agric. Sci. 18: 83-88.

Olafadehan, O.A. 2011a. Changes in haematological and biochemical diagnostic parameters of Red Sokoto goats fed tannin-rich Pterocarpus erinaceus forage diets. Vet. Arhiv 81: 471-483.

Olafadehan, O.A. (2011b). Carcass quality and cost-benefit of rabbits fed cassava peel meal. Arch. Zootec. 60: 757-765.

Olafadehan, O.A. 2013. Feeding value of Pterocarpus erinaceus for growing goats. Anim. Feed Sci. Technol. 185: 1-8. 
Olafadehan, O.A. and Adebayo, O.F. 2016. Nutritional evaluation of ammoniated ensiled threshed sorghum top as a feed for goats. Trop. Anim. Health Prod. 48: 785-791.

Olafadehan, O.A. and Okoye, G.C. 2017. Feed intake and blood profile of Red Sokoto goats fed urea treated ensiled cowpea husk based diets. J. Anim. Prod. Res. 29: 48-56.

Olafadehan, O.A., Olafadehan, O.O., Obun, C.O., Yusuf, A.M., Adewumi, M.K., Omotugba, S.K. and, Daniel, N.E. 2012. Influence of processing cassava peels on the hydrogen cyanide concentration, nutritive value and performance of growing rabbits Trop. Anim. Health Prod. 44: 285-291.

Olafadehan, O.A., Okunade, S.A. and Njidda, A.A. 2014. Evaluation of bovine rumen content as a feed. Trop. Anim. Health Prod. 46, 939945.

Olafadehan, O.A., Njidda, A.A., Okunade, S.A., Adewumi, M.K., Awosanmi, K.J., Ijanmi, T.O. and Raymond, A. 2016. Effects of feeding Ficus polita foliage-based complete rations with varying forage: concentrate ratio on performance and ruminalfermentation in growing goats. Anim. Nutr. Feed Technol. 16: 373-382.

Olafadehan, O.A., Njidda, A.A., Okunade, S.A., Salihu, S.O., Balogun, D.O. and Salem, A.Z.M. 2018. Performance and hemtochemical parameters of buck-kids fed concentrate partially replaced with tropical Piliostigma thonningii foliage. Anim. Sci. J. 89, 340-347.

Olafadehan, O.A., Okunade, S.A., Njidda, A.A., Kholif, A. E., Kolo, S.G. and Alagbe, J. O. 2020. Concentrate replacement with Daniellia oliveri foliage in goat diets. Trop. Anim. Health Prod. 52: 227-233.

Pascual, J. J. ; FernaHndez C.; DmHaz J. R.; Garces C. ; and RubertAlema J. 2000. Voluntary intake and in vivo digestibility of different date-palm fractions by Murciano-Granadina (Capra hircus). Journal of Arid Environments, (45): 183-189.

Reitman, S., and Frankel S. 1957. Colorimetric determination of GPT activity according to the Reitman and Frankel method. Am. J. Clin. Path., 28- 56.

Satter, L.D., and Slyter, L.L., 1974. Effect of ammonia concentration on rumen microbial protein production in vitro. Br. J. Nutr. 32, 199 208.

Siest, G.; Henny J, and Schiele F. 1981. Interprétions des examens de laboratoires, karger Ed., P. 206.

Van Soest, P.J.; Robertson J. B., and Lewis B.A. 1991, Methods for dietary fiber, neutral detergent fiber, and non-starch polysaccharides in relation to animal nutrition. J. Dairy Sci., 74: 3583-3597.

Villas-Boas, S.G.; Esposito E., and Mitchell D.A. 2002. Microbial conversion of lignocellulosic residues for production of animal feeds. Anim. Feed Sci. and Techno., 98:1-2.

Wang, Y.; McAllister T. A.; Rode L. M.; Beauchemin K. A.; Morgavi D. P.; Nsereko V. L.; Iwaasa A. D., and Yang W. 2001. Effects of an exogenous enzyme preparation on microbial protein synthesis, enzyme activity and attachment to feed in the Rumen simulation technique (Rusitec). Br. J. Nutr., (85): 325-332

Yang, W. Z., Beauchemin K. A., and Roda L. M. 1999. Effects of an enzymes feed additives on extent of digestion and milk production of lactating dairy cow. J. Dairy Sci. (82): 382:39

Publisher's note Springer Nature remains neutral with regard to jurisdictional claims in published maps and institutional affiliations. 